ophthalmoscope is responsible for this. The percentage of successful results was low in most places.

I cannot speak too highly of the kindness, hospitality, and courtesy which I encountered everywhere I went, and which made my visit so very enjoyable.

$$
\text { Yours, etc., }
$$

SOUTHAMPTON, 1938.

$$
\text { EDWARD C. ZORAB. }
$$

\title{
TRIAL FRAME SPIRIT LEVEL
}

\section{To the Editors of THE BRITISH JOURNAL OF OPHTHALMOLOGY.}

DEAR SIRS, - With regard to the trial frame spirit level device, Mr. McKie Reid obviously has priority by several years.

The device, which I first produced in 1935, was shown at the Oxford Congress (or rather the B.M.A. meeting which replaced it) and was shown subsequently at the North of England Ophthalmological Society-on whose agenda it appears in December, 1936.

I am afraid some of our mutual colleagues must be a little unobservant, as Mr. McKie Reid's letter is the first intimation I have had that anybody had produced a similar device.

I am glad to find that someone else has found the necessity for such an arrangement, as there quite a few cases in my opinion, in which it is necessary to use it.

Yours faithfully,

45, Park Square, Leeds, 1.

$$
\text { JOHN FOSTER. }
$$

October 11, 1938.

\section{OBITUARY}

\section{G. E. de SCHWEINITZ}

It is with great regret that we record the death of Dr. George Edmund de Schweinitz on August 22, 1938.

De Schweinitz was born in October, 1858, the son of Bishop Edmund de Schweinitz, of the Moravian Church, Bethlehem. He was educated at Bethlehem Moravian College and at the University of Pennsylvania Medical School, graduating in 1881. As an 
ophthalmologist de Schweinitz won international fame. He had been professor of ophthalmology at Jefferson Medical College and in the University of Pennsylvania. At various times he was President of the American Medical Association, the American Ophthalmological Society, the Academy of Natural Sciences and the American Philosophical Society. His well known text-book has passed through many editions and is popular in this country as well as in the United States. In 1930 he was awarded the Leslie Dana Medal for his work on prevention of blindness. In 1923 he delivered the Bowman Lecture before the Ophthalmological Society of the United Kingdom, its title was, "Concerning certain ocular aspects of the pituitary body disorders, mainly exclusive of the usual central and peripheral hemianopic field defects," 88 pages of the transactions are given to this noble effort. And since then he has been one of the small band of honorary members of the Society.

De Schweinitz served in France during the great war as Lieut.Colonel in the American Medical Force. He retired from active practice about two years ago when his health began to fail.

We are indebted to the Record of August 23 for much of the information abstracted here.

A mere catalogue of de Schweinitz's attainments gives a quite inadequate idea of his personality and of his outstanding position, not only in the history of ophthalmology but also of medicine in the United States. He was not only a great surgeon but also a great physician, and it was eminently apt that he should have held the presidency of the Philadelphia College of Physicians. It is unnecessary to give chapter and verse in this Journal for his work in ophthalmic medicine and surgery. It is well-known to all. His life was unremittingly devoted to ophthalmology and to the encouragement of medicine in the famous and old established University of Pennsylvania. An object which he had much at heart was the enrichment of the magnificent medical library in Philadelphia, and much of the time of his annual visits to this country was devoted to seeking out medical incunabula in London and elsewhere. de Schweinitz belonged to the type of American which we associate with New England, but which also flourishes in Pennsylvania - that erudite and highly cultured type, whose distrust of humbug and anything cheap engenders a reserve which can be as impenetrable as armour-plate. Only those who succeeded in overcoming this reserve can appreciate the sterling worth which it masks. To his accepted friends de Schweinitz was a delightful companion and a staunch comrade. His fame in the history of American medicine is assured.

J. H. P. 


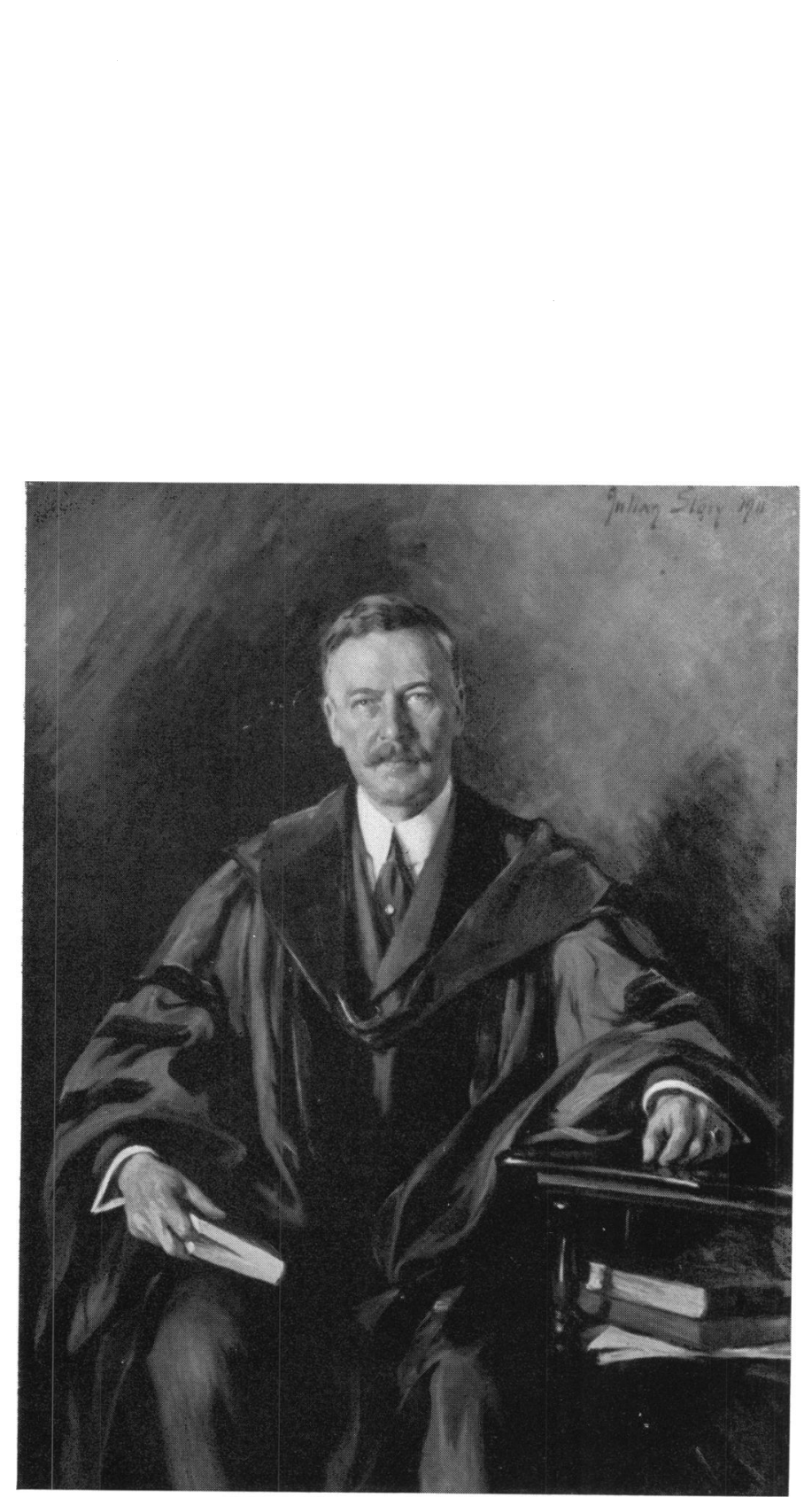

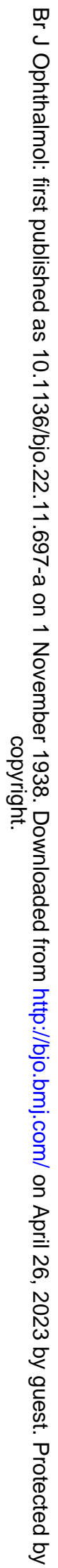




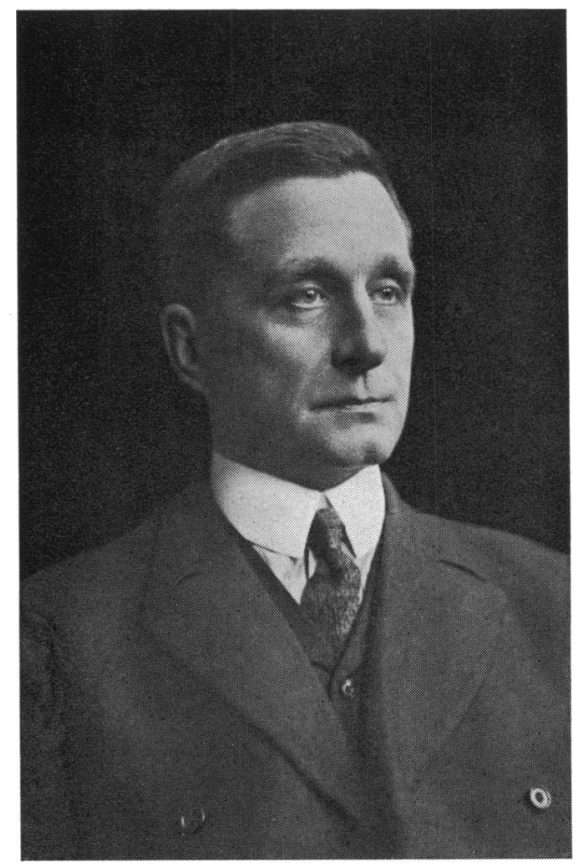

L. DE BI.ASKOVICS

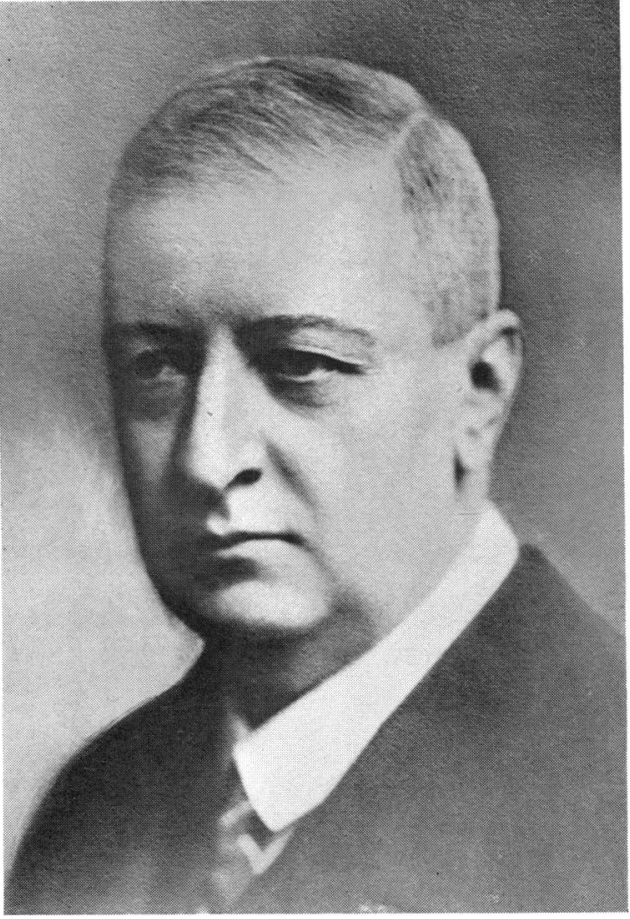

